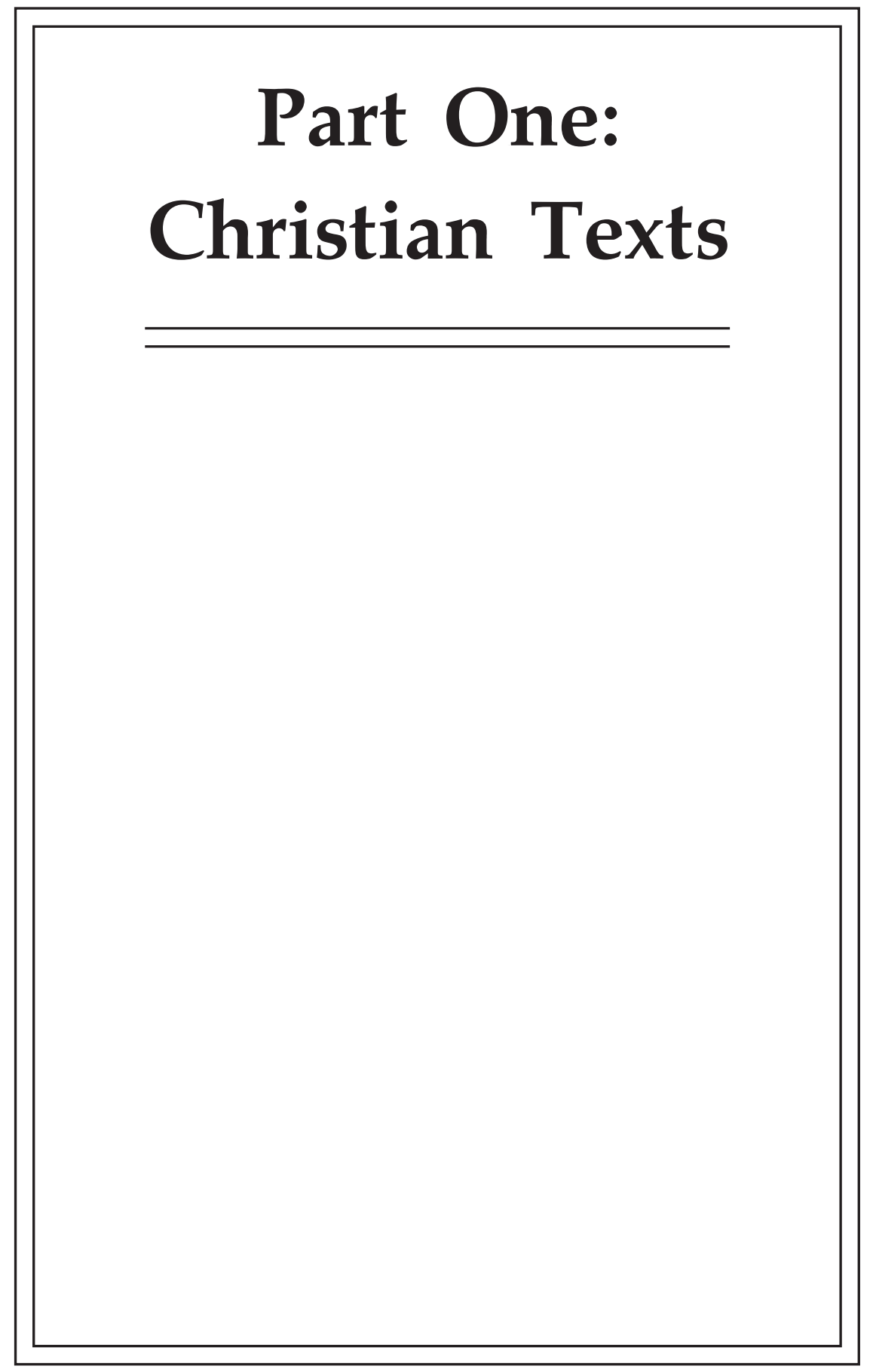




\section{THE ANGELOMORPHIC SPIRIT IN EARLY CHRISTIANITY: REVELATION, THE SHEPHERD OF HERMAS, CLEMENT OF ALEXANDRIA ${ }^{1}$}

The title of this essay is a deliberate allusion to John R. Levison's seminal article entitled «The Angelic Spirit in Early Judaism», which documented the widespread use, in pre- and post-exilic Judaism, of the term «spirit» as a designation of angelic presence. In the conclusion of his article, Levison formulated the following challenge to the scholarly community:

Discussions of the spirit of God in Early Judaism and Christianity ... ought to consider ... interpretations of the spirit as an angelic presence. ... The texts included in the present analysis serve ... to provide a suitable foundation for discussion of the angelic spirit in the Fourth Gospel, the Shepherd of Hermas, and the Ascension of Isaiah. ${ }^{2}$

The following pages are an attempt to take up the challenge, and pursue the occurrence of the «angelic spirit» (which I will henceforth refer to as «angelomorphic Pneumatology») in early Christian literature. ${ }^{3}$ In the first section of this essay, I will argue that angelomorphic Pneumatology figures prominently in the book of Revelation, the Shepherd of Hermas, and the Jewish Christian theology echoed by Clement of Alexandria's Eclogae Propheticae, Adumbrationes, and Excerpta ex Theodoto.

${ }^{1}$ This essay is part of a larger project dedicated to angelomorphic Pneumatology in the first four centuries. The sections on Clement of Alexandria and the Shepherd of Hermas are treated separately, but in greater detail, in my forthcoming articles: Revisiting Christian Oeyen: «The Other Clement» on Father, Son, and the Angelomorphic Spirit // VC 61 (2007); The Son of God and the Angelomorphic Holy Spirit: A Rereading of the Shepherd's Theology // ZNW 98 (2007) 1-23. For the initial impulse towards this area of research I am indebted to Dr. Michel René Barnes, my professor at Marquette University. I have learned from him, directly, just as much as I have indirectly, by arguing against some of his opinions. For a comprehensive presentation of early Christian doctrines of the Holy Spirit, the reader is referred to Dr. Barnes' soonto-be-published book on Pneumatology.

${ }^{2}$ J. LEVISON, The Angelic Spirit in Early Judaism // SBLSP 34 (1995) 464-493 (here 493; 492). See also his Spirit in First Century Judaism (Leiden, 1997) (AGJU, 29).

${ }^{3}$ For a survey of Jewish and early Christian materials that instantiate «angelomorphic Pneumatology», see Ch. GIEschen, Angelomorphic Christology: Antecedents and Early Evidence (Leiden, 1998) (AGJU 42) 114-119. 
The relation between angelomorphic Pneumatology and other occurrences in early Christian thought, such as angelomorphic Christology, Spirit Christology, or binitarianism, has not received adequate attention. How, for instance, does the Shepherd's oft-discussed Spirit Christology relate to the «angelic Spirit»? My thesis, for which the second part of the essay will accumulate evidence, is that the angelomorphic Pneumatology detected in Revelation, the Shepherd of Hermas, and Clement of Alexandria, always occurs within a binitarian theological framework, and in tandem with Spirit Christology. This larger theological articulation results in a quasi-Trinitarian structure of the divine world, featuring the Father, the Son/Spirit, and the angelomorphic Spirit.

The third and final section of the essay will sketch out a theological interpretation of these data. I submit that the concurrence of angelomorphic Pneumatology, Spirit Christology and binitarianism gives expression to a Trinitarian experience of God, articulated in the largely Jewish Christian idiom of early Christianity. ${ }^{4}$

\section{Angelomorphic Pneumatology in Early Christianity}

The terms «angelomorphic» and «angelomorphism» require some clarification. According to Crispin Fletcher-Louis, these terms are to be used «wherever there are signs that an individual or community possesses specifically angelic characteristics or status, though for whom identity cannot be reduced to that of an angel». ${ }^{5}$ The virtue of this definition - and the reason for my substituting the term «angelomorphic Pneumatology» for Levison's «angelic Spirit» - is that it signals the use of angelic characteristics in descriptions of God or humans, while not necessarily implying that the latter are angels stricto sensu: neither «angelomorphic Christology» nor «angelomorphic Pneumatology» imply the identification of Christ or the Holy Spirit with «angels». ${ }^{6}$

${ }^{4}$ Throughout this essay, the term «Jewish Christian» will be taken in the sense described by J. DaniÉLou in his classic work: The Theology of Jewish Christianity (London, 1964). As long as the narrative of an early and radical parting of the ways between «Christianity» and «Judaism» remains normative, despite its inability to explain a great deal of textual evidence from the first four centuries, the term «Jewish Christianity» remains useful as a description of «Christianity» itself. For more recent treatments of this problem, see the essays collected in A. H. BECKER, A. Y. REED (eds.), The Ways that Never Parted (Tübingen, 2003) (TSAJ, 95); D. BoYARIN, Border Lines: The Partition of Judaeo-Christianity (Philadelphia, Pa., 2004).

${ }^{5}$ C. Fletcher-Louis, Luke-Acts: Angels, Christology and Soteriology (Tübingen, 1997) (WUNT, 2/94) 14-15.

${ }^{6}$ It is important to caution against an anachronistic understanding of the terms «angel» or «spirit». According to Daniélou (Jewish Christianity, 118), «the use of such terms in no way implies that Christ was by nature an angel. ... The word angel... connotes a supernatural being manifesting itself. The nature of this supernatural be- 
In the words of Tertullian (De carne Christi 14), «dictus est quidem (Christus) magni consilii angelus, id est nuntius, oficii, non naturae vocabulo».

\section{The Angelomorphic Spirit in the Book of Revelation}

Revelation knows of a mysterious group of «seven spirits», mentioned repeatedly in Rev 1:4, 3:1, 4:5, and 5:6. The first of these references, which occurs in the opening blessing ( $\operatorname{Rev} 1: 4-5)$ is notoriously difficult to understand. Patristic exegesis as well as modern-day commentators have outlined the following alternatives:

(a) Revelation connects the seven spirits / eyes / lamps of the Lord (Zech $3: 9,4: 10$ ) with the rest/ tabernacling of the seven spiritual gifts (Isa 11:2, Prov 8:12-16); ${ }^{7}$

(b) Revelation connects the seven spirits / eyes / lamps of the Lord (Zech 3:9, 4:10) with the seven angels of the presence (Tob 12:15; 1 Enoch 90: $20-21){ }^{8}$

The exegetical impasse is evident. Patristic authors from the fifth century onwards are overcautious, given the potentially dangerous character of the passage. ${ }^{9}$ Modern exegetes tend to juxtapose the two solutions, rarely daring to eliminate either possibility. ${ }^{10}$

The angelic traits of these «spirits» are undeniable. They are depicted as standing before the divine throne ( $\operatorname{Rev} 1: 4 ; 4: 1)$, subject to Christ $(\operatorname{Rev} 3: 1)$,

ing is not determined by the expression but by the context. "Angel" is the old-fashioned equivalent of "person"». See also Ph. Henne, La Christologie chez Clément de Rome et dans le Pasteur d'Hermas (Fribourg, 1992) 225.

${ }^{7}$ This position is held by the vast majority of scholars, patristic and modern. The connection between Isa 11:2 (the seven gifts of the Spirit) and Zech 4:10 (the seven lamps) is an established topos in patristic exegesis. See K. ScHLÜTZ, Isaias 11:2 in den ersten vier christlichen Jahrhunderten (Münster, 1932) 34.

${ }^{8}$ This position is defended by J. Michl (Die Engelvorstellungen in der Apokalypse des hl. Johannes (Munich, 1937) and D. E. AunE (Revelation. 3 vols. (Dallas, Tex., 1997) (WBC 52) Vol. 1. 33-35). It should be noted that the impressive arsenal of primary and secondary literature deployed by these authors recommends this minority opinion as worthy of the same consideration as the majority position.

${ }^{9}$ I rely here on the fragments from patristic commentaries collected by H. B. SWETE (The Apocalypse of St. John: the Greek text with introduction, notes and indices (Grand Rapids, 1909) 5-6) and Michl (Die Engelvorstellungen... 113-134).

${ }^{10}$ Schweitzer simply juxtaposes the religio-historical perspective («from the point of view of the history of religion, they are simply the seven archangels»), and the traditional theological point of view, according to which the seven spirits «represent the Spirit of God in its fullness and completeness». E. SchweItzer, Spirit of God (Bible Key Words from Gerhard Kittel's Theologisches Wörterbuch zum Neuen Testament) (London, 1960) 105-106. Aune is exhaustive in his references, but very reserved in advocating the identification between the seven spirits and the principal angels (AunE, Revelation... 34). 
so as to be sent out throughout the world (Rev 5:6). Needless to say, these are standard elements in the depiction of angelic intercession, contemplation and service. In fact, Revelation also knows of «the seven angels before the throne» (Rev 8:2). Since both «angels» and «spirits» are well-defined groups (the seven spirits, the seven angels), it is most likely that they refer to the same reality. ${ }^{11}$

Here we find a definite echo of the Jewish and Jewish-Christian traditions about the highest angelic company. ${ }^{12}$

The use of $\pi v \varepsilon \cup \hat{\mu} \mu$ language to designate angelic beings does not surprise. Far from being a Christian invention, much less a peculiarity of Revelation, this phenomenon is present in the Hebrew Bible, the LXX and various authors of the Alexandrian diaspora, and at Qumran. ${ }^{13}$ In Isa 63:9-10 the Angel of the Lord is referred to as «holy spirit». In the New Testament, it is usually evil angels that are referred to as (impure) «spirits», but one also finds

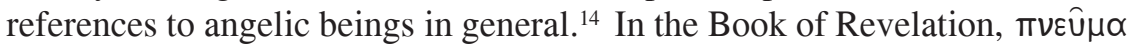
is used twice for angelic beings, namely evil ones (Rev 16:13-14; 18:2). But

${ }^{11}$ Aune, Revelation... Vol. 1. 33. P. Prigent (Commentary on the Apocalypse of St. John (Tübingen, 2001) 117), points to Rev 3:1 («...these things says He who has the seven spirits of God and the seven stars...») as proof that the seven spirits are different from the seven stars, identified in Rev 1:20 with the seven angels. However, it makes perfect sense to understand koí as epexegetical.

12 The group of seven is found in Ezekiel 9:2-3 (seven angelic beings, of which the seventh is more important than the other six), Tob 12:15 (seven «holy angels» who have access before the Glory, where they present the prayers of «the saints»), and 1 Enoch (ch. 20: seven archangels; ch. 90:21, «the seven first snow-white ones»). The notion of «first created» is important to the author of Jubilees: the angels of the presence are said to be circumcised from their creation on the second day, thus possessing a certain perfection and functioning as heavenly models and final destination of the people of Israel (Jub 2:2; 15:27). The Prayer of Joseph seems to imply that Israel ranks higher than the seven archangels, as chief captain and first minister before the face of God. For a list of references to «angel / angels of the face» in the Pseudepigrapha, see C. L. SEow, Face // Dictionary of Deities and Demons in the Bible / Ed. K. van der Toorn, B. Becking, P. W. van der Horst (Leiden-Boston-Grand Rapids, 1999) 322-325. Relevant passages are Jub 2:2, 18; 15:27; 31:14; T. Levi 3:5; 4:2; T. Judah 25:2; 1 QH 6:13. In 2 En 19:1, a group of seven angels is placed in the sixth heaven. See also J. C. VANDERKam, The Book of Jubilees (Sheffield, 2001) 87-89, 126-127; GIESCHEN, Angelomorphic Christo$\log y \ldots 124-151$.

${ }^{13}$ Levison, The Angelic Spirit..., passim; A. E. SekKI, The Meaning of Ruach at Qumran (Atlanta, Ga, 1989) (SBLDS, 110) 145-171.

${ }^{14}$ Aside from the designation of evil angels as (impure) «spirits», the equivalence of «spirit» and «angel» is implicit in Heb 1:14 (angels are «ministering spirits»), Heb 12:9 («Father of spirits»), and Acts 8:26.29.39, where the text seems to alternate between «angel of the Lord», «spirit», and, «spirit of the Lord». 


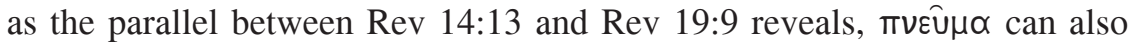
indicate a good angel. ${ }^{15}$

On the other hand, the Pneumatological content of Rev. 1:4 is equally clear. The seven «first created spirits» are one of the three coordinated entities (God and the seven spirits and Jesus Christ) invoked as senders of grace and peace. Since the blessing with «grace and peace» can only be divine, ${ }^{16}$ the three must, in some way, stand for the divinity (cf. 2 Cor 13:14, The grace of the Lord Jesus Christ, and the love of God, and the communion of the Holy Spirit, be with you all). ${ }^{17}$ This is why it seems most likely that the mentioning of the «seven spirits» corresponds to the expected reference to the Holy Spirit. In other words, the author's expression «seven spirits» would designate what the early Church more often referred to as «Holy Spirit». The greeting in Revelation is therefore Trinitarian. It is a «grotesque» Trinity, or one that is «quite orthodox», depending whether or not one chooses to consider it in its proper context, which is that of Jewish apocalyptic traditions appropriated by early Christians. ${ }^{18}$

${ }^{15} \operatorname{Rev} 14: 13$ : «And I heard a voice from heaven saying, "Write this: Blessed are the dead who from now on die in the Lord!" "Yes", says the Spirit (the initial locutor, the voice), "they will rest from their labors, for their deeds follow them"»; Rev 19:9: "And the angel said to me, "Write this: Blessed are those invited to the marriage supper of the Lamb!" And said he (the initial locutor, the angel) to me, "These are true words of God!"» From a form-critical perspective, both passages are examples of the so-called promise-to-the-victor, a type of statement that occurs fairly often in the Book of Revelation. In both passages, an initial declaration is repeated and confirmed by the same heavenly locutor. The difference consists only in the fact that we read «spirit» in Rev 14:13, and, respectively, «angel» in Rev 19:9. Yet, in light of the structural similarities in structure and content, and given the interchangeability of the terms «angel» and «spirit» in early Jewish and Christian texts, I believe that the case under discussion is another example of $\pi v \varepsilon \hat{u} \mu \propto$ language in the service of angelology.

${ }^{16}$ Pace Michl (Die Engelvorstellungen... 155-156). Michl tries to escape the difficulty by interpreting the blessing with «grace and peace» coming from the angels as «eine Spendung im uneigentlichen Sinne» (156). On the other hand, he adduces a number of Jewish and Christian texts in which angels appear to hold a certain exalted status in their relations with humans. The difficulty of Rev 1:4, however, is due to the fact that angels appear to be placed on the same level with the Father and the Son!

${ }^{17}$ See also the list of passages illustrating Paul's «soteriological trinitarianism» in G. FeE, Christology and Pneumatology in Romans 8:9-11 and Elsewhere: Some Reflections on Paul as a Trinitarian // Jesus of Nazareth Lord and Christ: Essays in the Historical Jesus and New Testament Christology / Ed. M. Turner, J. B. GreenE (Grand Rapids, 1994) 312-331, here 329-330.

18 These are the terms used by R. H. Charles, A Critical and Exegetical Commentary on the Revelation of St. John (Edinburgh, 1920) iv; and G. Dix, The Seven Archangels and the Seven Spirits: A Study in the Origin, Development, and Messianic Associations of the Two Themes // JTS 28 (1927) 233-250, here 248. 


\section{The Angelomorphic Spirit in the Shepherd of Hermas ${ }^{19}$}

Very similar to the seven spirits / angels of Revelation are the seven «first

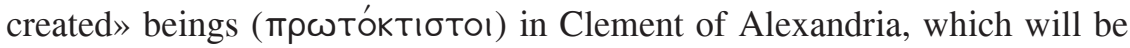
discussed later in this essay. Before Clement, and certainly one of his sources, the Shepherd of Hermas knows of a group of seven consisting of the six angel «first created» ( as their seventh (Vis 3:4:1; Sim 5:5:3). ${ }^{20}$ They hold the highest position in a world of angelic spirits. But the Shepherd contains several passages that support the case for angelomorphic Pneumatology.

(a) Mand 11 discusses at length the action of the inspiring agent upon the Christian prophet, the complex relationship between the prophet and his audience, and the distinction between true and false prophets. Up to Mand 11.9, the text uses only «spirit» language, giving advice about how to discriminate between the divine spirit and the earthly spirit, and describing their respective activities in the authentic and, respectively, the false prophet. Then, in Mand 11.9, the text uses «angel» for the very same reality that it had described as an indwelling «spirit». ${ }^{21}$ As for the «angel of the prophetic spirit»,

${ }^{19}$ Greek text in M. Leutzsch, Papiasfragmente. Hirt des Hermas (Darmstadt, 1998). In submitting to the current scholarly consensus, I assume that the Shepherd of Hermas is a unitary text, dating from the early decades of the second century. See the firm conclusions of R. JolY, Hermas et le Pasteur // VC 21 (1967) 201-218, echoed in the most recent commentaries on the Shepherd: N. Brox, Der Hirt des Hermas (Göttingen, 1991) (KAV, 7); C. Osiek, Shepherd of Hermas (Minneapolis, Minn., 1999) (Hermeneia). While the scholarly consensus seems to have settled around the year 140 , with a tendency towards the earlier part of the second century (BROx, Der Hirt... 22-25), Osiek (Shepherd Commentary... 20b) concludes on «an expanded duration of time beginning perhaps from the very last years of the first century, but stretching through most of the first half of the second century». Leutzsch proposes the interval 90-130.

${ }^{20}$ By referring almost in the same breath to the Son and the first-created angels (Sim 5.2.6, 11; Sim 5.6.4,7), the Shepherd suggests that, even though they are clearly subordinated to the Son of God, and accompany him as a celestial escort (e.g., Sim

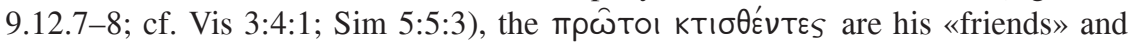
fellow-counselors (Sim 5.5.2-3). As noted by DANIÉLOU (Jewish Christianity... 38), «the Word appears as the chief of the six archangels, being himself the seventh».

${ }^{21}$ «So when the person who has the spirit of God enter the assembly of just men

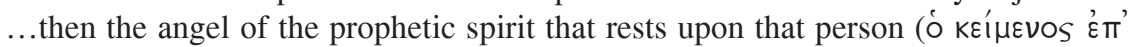

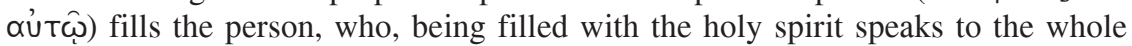

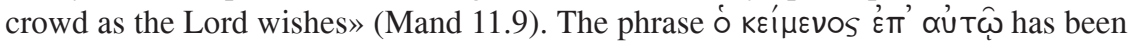
translated in various other ways: «qui est près de lui» (Joly); «in charge of him» (Reiling, Gieschen); «der bei ihm ist» (Brox). See the very helpful survey and discussion in J. Chr. WILSON, Toward a Reassessment of the Shepherd of Hermas: Its Date and Pneumatology (Lewiston-Queenston-Lampeter, 1993) 97. 
a fruitful comparison can be made with «the angel of the Holy Spirit» in the Ascension of Isaiah, and, by analogy with the «angel of penitence» in Vis 5.7, with «the angel presiding over genuine visions» in 2 Bar. and $3 \mathrm{Bar}^{22}$ Inter- $^{2}$ estingly, in all cases the reference is to an angelic being (Ascension of Isaiah identifies the «angel of the Lord» in Mat 1:20.24 with the angel of the Holy Spirit, 9:36 and 11:4; Ramiel in 2 Bar.; Phamael in 3 Bar.). This expression may, therefore, be included in Levison's category «angelic spirit». ${ }^{23}$

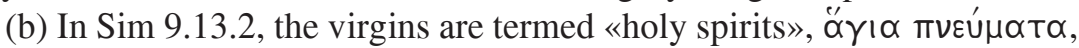

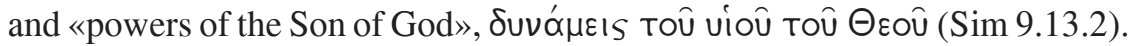
To be clothed with these «powers» means to bear the «power» of the Son of God ( $\operatorname{Sim}$ 9.13.2). In other words, the Son of God is active in the believer through these «powers» or «spirits». ${ }^{24}$ The deployment of clothing and baptismal language suggests that the virgins can be seen as a plural designation of the Holy Spirit. In describing the eschatological state of those who have the Spirit, the Shepherd uses the following expressions: «always clothed with the holy spirit of these young women» (Sim 9.24.2); «you have received something of his [the Lord's] spirit» (Sim 9.24.4); «they received the Holy Spirit» (Sim 9.25.2). Believers must «clothe themselves with these spirits» (Sim 9.13.2), as a result becoming «one body, one spirit, and one color of garment» (Sim 9.13.5). The white color of the garment finds a symbolic counterpart in the white color of the tower: «So stones of many different colors were brought... And when the variegated stones were put into the building, all alike became white and changed their many colors» (Sim 9.4.5-6). The tower built on water, the white garment, the transformation into «one spirit» obviously refer to Baptism and the receiving of the Holy Spirit. Indeed, the Shepherd of Hermas collapses the spirits and the Spirit in his exhortation to repentance and holiness: "give back the spirit (reddite spiritum, L1) as whole as you have received it! ... what do you think the Lord will do to you, who gave you the spirit (spiritum dedit) whole, but you gave it back useless?»

${ }^{22}$ Ascension of Isaiah 7:23, 8:12, 9:36.39.40, 11:4; 2 Bar. 55:3; 3Bar 11:7. J. REILING (Hermas and Christian Prophecy: A Study of the Eleventh Mandate (Leiden, 1973) (NovTSup, 37) 106) rejects this equation arguing that the Shepherd does not mention an angel «of prophecy», but rather «of the prophetic spirit».

${ }^{23}$ Gieschen (Angelomorphic Christology... 218) notes that «this angel is much more than another angel with a specific function», and that he is «closely linked with "the Spirit"». Gieschen identifies the «angel of the prophetic spirit» as an angelomorphic manifestation of the Holy Spirit.

${ }^{24}$ Cf. Levison (The Angelic Spirit... 469), who argues that the metaphor of clothing in Judg 6:34 «is consistent with the interpretation of the spirit as an angelic or demonic being». For the use of «power», see the brief but very dense overview, see Gieschen, Angelomorphic Christology... 119-123 («Power as designation for an Angel»). Among the relevant passages: Philo, Conf 168-182, Rom 8:38, 1 Cor 15:24, Eph 1:21; 1 Pet 3:22. 
(Sim 9.32.2, 4). ${ }^{25}$ Being «clothed with these spirits» (Sim 9.13.2), which are the «powers» of the Son, means, then, to receive the white garment of Bap-

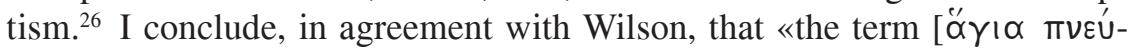
$\mu \propto \tau \alpha]$ does signify a plural concept of the Holy Spirit». ${ }^{27}$

(c) There exists a structural similarity between Mand 5 and Mand 6: both make certain statements of spiritual and psychological dualism, continue with a rather detailed symptomatology and prognosis for each alternative, and conclude with an exhortation to choose the good. At the level of vocabulary, however, Mand 5 uses «spirit», while Mand 6 has «angel». ${ }^{28}$ The parallelism is particularly notable between «the spirit of righteousness» in Mand 5.2.7, and «the angel of righteousness» in several verses of Mand 6.2. Moreover,

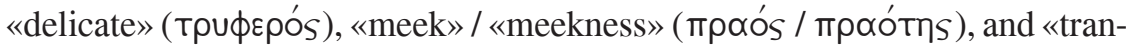

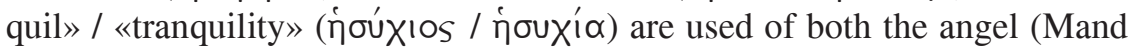
6.2.3) and the «spirit» (Mand 5.2.6). ${ }^{29}$

So far, it appears that the «spirits» have undeniable angelic traits. It is just as true, however, that the angel of righteousness in Mand 6 conveys a pneumatological content. In this respect, I have already mentioned the «delicacy» of the Holy Spirit. Another crucial indicator are the terms ñoúxı $x^{\prime} \propto \alpha$, whose quasi-technical status in describing the abiding presence of the

${ }^{25}$ Leutzsch prefers to include L2 in the text: habebitis spiritum, «you shall have the spirit». However, L1 makes better sense in connection with Sim 9.32.4.

${ }^{26}$ Irenaeus equates the divine garment with the Holy Spirit (Adv. haer. 3:23:5; 4:36:6). The Shepherd's affirmation that «one cannot be found in the reign of God unless they [the virgins] clothe you with their garments» (Sim 9.13.2) finds perfect counterpart in Irenaeus' theology of the paradisiac, baptismal, and eschatological garment, equated with the gift of the Holy Spirit. See Y. DE ANDIA, Homo Vivens: Incorruptibilité et divinisation de l'homme chez Irénée de Lyon (Paris, 1986) 97-99.

${ }^{27}$ WILSON, Reassessment... 154, n. 129.

${ }^{28}$ Each person is attended by two spirits (Mand 5.1.4) or angels (Mand 6.2.1). The criterion for distinguishing the influence of the good angel or spirit from that of the evil one is the experience and subsequent conduct of the indwelled person (Mand 5.2.1-3; Mand 6.2.3-4). One is to trust the good spirit (Mand 11.17, 21) or angel (Mand 6.2.3), and depart from the evil spirit or angel (Mand 6.2.7; Mand 5.2; Mand 11.17).

${ }^{29}$ The theme of the Spirit's «delicacy» seems to have been taken over by none other than Tertullian, otherwise a harsh critic of the Shepherd. See J. E. MorganWynne, The «Delicacy» of the Spirit in the Shepherd of Hermas and in Tertullian // SP 21 (1989) 154-157. H. OpITz (Ursprünge Frühkatholischer Pneumatologie (Berlin 1960) 140-141) traces the «delicacy of the Spirit» to Jewish-Christian exegesis of 1 Sam 16:14-15 (LXX). The fact that the Shepherd of Hermas is aware of an old tradition of dualist pneumatology rooted in the exegesis of 1 Sam 16:14 has been proven by recourse to similar passages in Aphrahat. See N. IBrahim Fredrikson, L'Esprit Saint et les esprits mauvais dans le pasteur d'Hermas: Sources et prolongements // VC 55 (2001) 262-280, esp. 273-275. 
Holy Spirit has been demonstrated by Gabriele Winkler. ${ }^{30}$ It appears, therefore, that the Shepherd retains the use of «spirit» language for angelic beings, but also deploys «angel» language and imagery to speak about the Holy Spirit. In short, we find in the Shepherd both «spirit» angelology and angelomorphic Pneumatology.

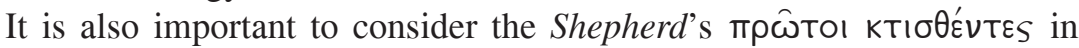
religio-historical perspective. There can be no question that this collective character is an echo of angelological speculations common in Second Temple Judaism. Such traditions about the highest angelic company underwent considerable modifications under the influence of the early Christian kerygma. One example would be the subordination of the supreme angels to the Son of God, a subordination that is quite obvious in the Shepherd and Revelation. A second change in the status of the seven angels consists in their overlap with the Holy Spirit. I have already mentioned this phenomenon in Revelation. A case has been made for the close association (bordering on identification) between the seven spirits and the Holy Spirit in the writings of Justin Martyr. ${ }^{31}$ But the most significant witness is that of Clement of Alexandria.

\section{The Angelomorphic Spirit in Clement of Alexandria}

Clement of Alexandria is one of our most eminent witnesses of secret traditions ascribed to the apostles and circulating among Jewish Christian teachers during the first three centuries of the common era. ${ }^{32}$ It is especially in the much neglected Excerpta ex Theodoto, Eclogae Propheticae, and Adumbrationes that he is echoing the theology and practices of earlier Jewish Christian teachers. These are remnants from Clement's otherwise lost Hypotyposeis, a work for advanced students, where the Alexandrian also treated of the Holy Spirit, the soul, and prophecy. ${ }^{33}$

${ }^{30}$ For ample documentation and a very detailed analysis, see G. WINKLER, Ein bedeutsamer Zusammenhang zwischen der Erkenntnis und Ruhe in Mt 11, 27-29 und dem Ruhen des Geistes auf Jesus am Jordan. Eine Analyse zur Geist-Christologie in Syrischen und Armenischen Quellen // Mus 96 (1983) 267-326.

${ }^{31}$ Ch. Oeyen, Die Lehre von den göttlichen Kräften bei Justin // SP 11 (1972) 214-221.

32 See J. DaniÉLou, Les traditions secrètes des Apôtres // Eranos Jahrbuch 31 (1962) 199-215; G. G. StroumsA, Clement, Origen, and Jewish Esoteric Traditions // Hidden Wisdom: Esoteric Traditions and the Roots of Christian Mysticism (Leiden, 1996) 109-131; IDEM, Paradosis: Esoteric Traditions in Early Christianity // Hidden Wisdom... Esp. 42-43.

${ }^{33}$ P. NAutin, La fin des Stromates et les Hypotyposes de Clément d'Alexandrie // VC 30 (1976) 268-302, esp. 297-298, has demonstrated that they represented Clement's physics and epoptics. To quote A. MéHAt (Etude sur les «Stromates» de Clément d'Alexandrie [Paris, 1966] 521), «[b]ref, si la gnose est essentiellement du domaine de la "physique", les Hypotyposes devaient en regorger...» Although Nautin 
I am indebted here to Christian Oeyen's Eine frühchristliche Engelpneumatologie bei Klemens von Alexandrien (Bern, 1966), one of the few studies of Clement's Pneumatology, and perhaps the only one to emphasize the Jewish Christian heritage in Clement's theology. ${ }^{34}$ Underlying Clement's Pneumatology is the «hierarchical» cosmology inherited from Jewish and early Christian apocalypticism, and the philosophical concern to articulate divine unity and the multiplicity of the cosmos.

\section{Unity and Multiplicity in the Spirit}

In Strom. 5:6, Clement provides an allegorical interpretation of the Old Testament Temple and its furnishings. Clement's exegesis follows a recognizable pattern: he introduces the object of interpretation, offers a first level of explanation, then a second one. The first level of explanation is astrological: the lamp signifies «the motions of the seven planets that perform their revolutions towards the south»; the cherubim signify the two bears, or the two hemispheres, the twelve wings and twelve stones describe for us the circle of the zodiac. ${ }^{35}$

A second level of interpretation is Christological:

The golden lamp conveys another enigma as a symbol of Christ ... in his casting light, «at sundry times and diverse manners», on those who believe on Him and hope, and who see by means of the ministry of the protoctists

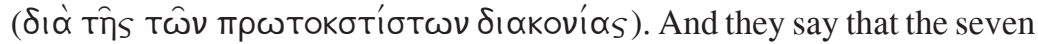
eyes of the Lord are the seven spirits resting on the rod that springs from the root of Jesse. ${ }^{36}$

does treat the Adumbrationes (his study is confined to the Codex Laurentianus) it is easy to see how these passages also belong to the epoptics. See MéHAt, Etude... 517522; 530-533.

34 This booklet, published in Bern, in 1966, is a slightly revised version of Ch. OEYEN, Eine frühchristliche Engelpneumatologie bei Klemens von Alexandrien // IKZ 55 (1965) 102-120, and IKZ 56 (1966) 27-47. For Clement's Pneumatology, an altogether understudied area in Patristic studies, see also W.-D. HauschILD, Gottes Geist und der Mensch: Studien zur frühchristlichen Pneumatologie (München, 1972); L. LADARIA, El Espíritu en Clemente Alejandrino: estudio teológico antropológico (Madrid, 1980); H. ZIEBRITZKI, Heiliger Geist und Weltseele: das Problem der dritten Hypostase bei Origenes, Plotin und ihren Vorläufern (Tübingen, 1994) 93-129. See also my «Revisiting Christian Oeyen», referred to at the beginning of this essay. For the anthropological

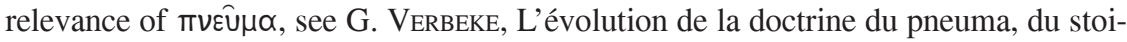
cisme à s. Augustin: étude philosophique (Paris-Louvain, 1945) 429-440.

35 This interpretation is not Clement's own creation. Cf. Philo, On the Cherubim VII:21-24. For a comprehensive survey of Clement's debt to Philo in his exegesis of the Temple, the vestments and the high priest, see A. VAN DEN HoEK, Clement of Alexandria and His Use of Philo in the Stromateis: an Early Christian Reshaping of a Jewish Model (Leiden, 1988) 116-147.

${ }^{36}$ Clement of Alexandria, Strom. 5:6:35. 
Here Clement draws on a series of Biblical passages (Isa 11:1-2; Zech 4:2, 10 ; Rev $1: 4 ; 5: 6 ; 8: 2)$ that might have already been combined by earlier tradition. Zechariah's seven spirits (eyes of the Lord) are Isaiah's seven gifts of the Holy Spirit, and the angelomorphic imagery, implicit in Revelation, is here affirmed explicitly: the seven «spirits» are, in fact, the seven celestial entities

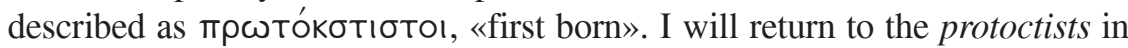
the next section of this paper. Consistent with the Christological framework in which he places the Old Testament prophecies and theophanies throughout his writings, Clement strictly subordinates the seven angelic spirits to work of the Logos. ${ }^{37}$ The entire discussion about unity and multiplicity seems to presuppose, in descending order, the Father, the Son, and the protoctists. Confirmation of this idea, and a much more detailed description of the hierarchy, is provided by Clement's Excerpta ex Theodoto and the Adumbrationes.

\section{Clement of Alexandria's "Celestial Hierarchy» ${ }^{38}$}

On the basis of a theological tradition inherited from primitive Jewish Christian circles, Clement furnishes, especially in Excerpta 10, 11, and 27, a detailed description of the spiritual universe. ${ }^{39}$ This celestial «hierarchy» if the anachronism is acceptable - features, in descending order, the Face, the seven first created angels, the archangels, and finally the angels. ${ }^{40} \mathrm{To}$

${ }^{37}$ It is noteworthy that the brief quotation from Heb 1:1 («at sundry times and diverse manners») is also subtly molded into an explicitly Christological affirmation: the one speaking «at sundry times and diverse manners» to the fathers is, originally, «God»; Clement, however, speaks about Christ casting his light «at sundry times and diverse manners».

${ }^{38}$ For a detailed presentation of Clement's account, see B. G. Bucur, The Other Clement of Alexandria: Cosmic Hierarchy and Interiorized Apocalypticism // VC 60 (2006) 251-268.

39 The fact that Clement's strictly hierarchical universe goes back to earlier tradition has been demonstrated by older research: P. Collomp, Une source de Clément d'Alexandrie et des Homélies Pseudo-Clémentines // Revue de philologie et littérature et d'histoire anciennes 37 (1913); W. BoussET, Jüdisch-christlicher Schulbetrieb in Alexandria und Rom: Literarische Untersuchungen zu Philo und Clemens von Alexandria, Justin und Irenäus (Göttingen, 1915). Despite the pertinent critique of some of Bousset's conclusions (J. MuncK, Untersuchungen über Klemens von Alexandria (Stuttgart, 1933) 127-204), the thesis of a Jewish and Jewish-Christian literary source behind Clement remains solidly established: G. KRETSCHMAR, Studien zur frühchristlichen Trinitätstheologie (Tübingen, 1956) 68, n. 3; DANIÉLou, Les traditions secrètes des Apôtres... 214; M. Roncaglia, Pantène et le Didascalée d'Alexandrie: du judéo-christianisme au christianisme hellénistique // A Tribute to Arthur Vööbus: Studies in Early Christian Literature and its Environment, Primarily in the Syrian East / Ed. R. H. FISCHER (Chicago, 1977) 211-233.

${ }^{40}$ The term «hierarchy» was coined centuries later by the anonymous author of the Pseudo-Areopagitic Corpus. Nevertheless, the multi-storied cosmos that charac- 
describe the continual propagation of light from the Face down to the lowest

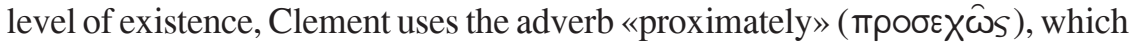
suggests immediacy, the lack of any interval between the levels. Each rank of spiritual entities is «moved» by the one above it, and will, in turn, «move» the immediately lower level. ${ }^{41}$

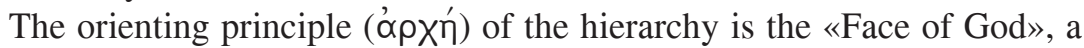
theme whose prominence in the apocalyptic literature of Second Temple Judaism was only amplified with the emergence of Christianity. ${ }^{42}$ For Clement, the Face of God is the Son». ${ }^{43}$

The first level of celestial entities contemplating the Face is constituted

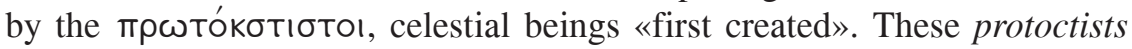
are seven, but they are simultaneously characterized by unity and multiplicity: although distinct in number, Clement writes, «their liturgy is common and undivided». ${ }^{44}$ On the one hand, the protoctists are numbered with the angels and archangels, their subordinates. ${ }^{45}$ On the other hand, they are bearers of

terizes apocalyptic writings such as the Ascension of Isaiah, 2 Enoch or the Epistula Apostolorum can also be labeled «hierarchical». Moreover, there are some surprising similarities between the Clementinian and Dionysian «hierarchies» (see the brief note by A. Golitzin, Et Introibo Ad Altare Dei: The Mystagogy of Dionysius Areopagita, with Special Reference to its Predecessors in the Eastern Christian Tradition (Thessalonica, 1994) (Analekta Vlatadon, 59) 265).

${ }^{41}$ Strom. 6:16:148 offers a veiled description of the same hierarchical reality:

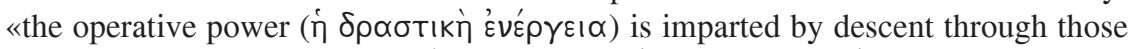

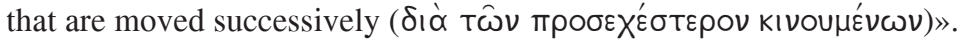

${ }^{42}$ Seow, Face... 322-325. For a theological evaluation of the theme of the Face in the Pseudepigrapha, see A. OrLov, The Enoch-Metatron Tradition (Tübingen, 2005) (TSAJ, 107), and his articles «Exodus 33 on God's Face: A Lesson From the Enochic Tradition» and «The Face as the Heavenly Counterpart of the Visionary in the Slavonic Ladder of Jacob», republished in A. OrLov, From Apocalypticism to Merkabah Mysticism: Studies in the Slavonic Pseudepigrapha (Leiden, 2006) (JSJ, 114) 311325, 399-419. See also A. DE Conick, Heavenly Temple Traditions and Valentinian Worship: A Case for First-Century Christology in the Second Century // The Jewish Roots of Christological Monotheism / Ed. C. C. Newman, J. R. Davila, G. S. Lewis (Leiden, 1999) (JSJ, 63) 327-329.

${ }^{43}$ Excerpta 10:6; 12:1. According to April De Conick (Heavenly Temple Traditions... 325), «the image of the Son as the Father's Face may have played a significant role in Valentinian theologies». However, the repeated occurrence of the same designation in Clement of Alexandria (Paed 1:57 and 1:124:4, Strom 7:58, as well as in Tertullian ( $A d v$. Prax. 14), suggests that «Face» as a Christological title was at least as popular in mainstream Christianity as it was in Valentinian tradition.

${ }^{44}$ Excerpta 10:3-4; 11:4.

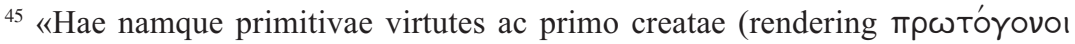

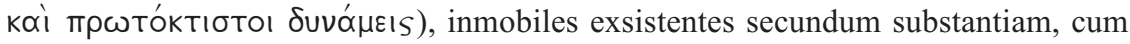
subiectis angelis et archangelis» (Adumbrationes in 1 Jn 2:1). Stählin's critical edition introduces a comma between «inmobiles» and «exsistentes». I prefer to revert to 
the divine Name, and, as such, are called «gods». ${ }^{46}$ Clement equates them with «the seven eyes of the Lord» (Zech 3:9, 4:10; Rev 5:6), the «thrones» (Col 1:16), and the «angels ever contemplating the Face of God» (Mat 18:10). ${ }^{47}$ The protoctists fulfill multiple functions: in relation to Christ, they present the prayers ascending from below (Excerpta 27:2); on the other hand, they function as «high priests» with regard to the archangels, just as the archangels are «high priests» to the angels, and so forth (Excerpta 27:2). In their unceasing contemplation of the Face of God, they represent the model ( $\pi \rho \circ-$

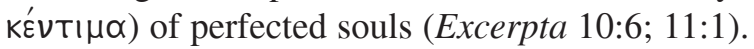

The cosmological scheme described in Strom. 5:6 or in the Excerpta seems to reserve no place to the Holy Spirit. In descending order, one reads about the Father, the Son, and the protoctists. The relation between the seven protoctists and the Holy Spirit becomes clear in the passages outlining Clement of Alexandria's theory of prophetic inspiration.

\section{Clement's Theory of Prophetic Inspiration}

Clement is aware of the two major functions traditionally ascribed to the Holy Spirit, namely the inspiration of Old Testament prophets and the indwelling of the believers. ${ }^{48}$ However, he oftentimes ascribes the same func-

Zahn's text, which has no comma. Thus, I take «inmobiles exsistentes secundum substantiam» to mean that their substance is immovable according to substance, i.e., does not undergo change. A number of scholars (Zahn, Kretschmar, Barbel) identified these «powers» with two paracletes; on the other hand, the idea that the «powers» under discussion are the seven protoctists is supported by François Sagnard, the editor and translator of the Excerpta for Sources Chrétiennes (Excerpta 77, n. 2), and, more recently, by ZIEBRITZKI (Heiliger Geist und Weltseele... 122, n. 148). But the most extensive argumentation has been furnished by OEYEN (Engelpneumatologie... 31-33).

${ }^{46}$ «Now, in the Gospel according to Mark, when the Lord was interrogated by the high priest if He was "the Christ, the Son of the blessed God", He answered saying, "I am; and you shall see the Son of man seated at the right hand of power (a dextris virtutis)". But "powers" indicates the holy angels. Further, when He says "at the right hand of God", he means the same ones, on account of the equality and likeness of the angelic and holy powers, which are called by the one name of God (quae uno nominabantur nomine dei)» (Adumbrationes in Juda 5:24). Clement equates here «power» in the Gospel text with «angels»; in an earlier sentence, he had equated «glory» with «angels»: «In the presence of His glory: he means before the angels...» (Adumbrationes in Juda 5:24).

${ }^{47}$ Excerpta 10; Eclogae 57:1. For a synthetic presentation of the protoctists, see A. Le Boulluec, Commentaire // Clément d'Alexandrie, Stromate V. Tome 2 (Paris, 1981) (SC, 279) 143.

48 «The Holy Spirit, by Isaiah, denounces...» (Paed 2:1:8); «the Holy Spirit, uttering His voice by Amos» (Paed 2:2:30); «the Spirit prophesies by Zephaniah» (Paed 2:12:126); «the Spirit [says] by Solomon» (Paed 2:12:129). Excerpta 24:2 affirms 
tions to the Logos, even while maintaining some role for the Holy Spirit. He affirms, for instance, that the Logos «tunes» both the great cosmos and the

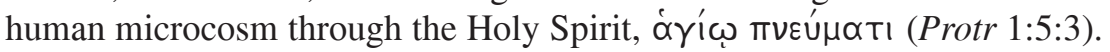

«The Logos through the Spirit»: this expression is given a precise explanation in Eclogae 51-52. Here Clement describes the phenomenon of prophecy as follows: the Logos moves the first rank of the protoctists, this movement is transmitted from one level of the angelic hierarchy down to the next; and the lowest angelic rank, which is the one closest to the human world, transmits the «movement» to the prophet. In this light, it becomes clear how Clement understands the traditional statements about the Logos speaking to the prophets: the prophet experiences the presence and message of the Logos by receiving the «energy» of the proximate angel. ${ }^{49}$ Here are two of the texts that treat prophecy in more detail:

It is declared thereby that the prophets conversed with Wisdom, and that there was in them the Spirit of Christ, in the sense of possession by Christ, and subjection to Christ (secundum possessionem et subiectionem Christi). For the Lord works through archangels and through angels that are close (per ... propinquos angelos), who are called «the Spirit of Christ» (qui Christi vocantur spiritus). ${ }^{50}$...He says, «Blessed are you, because there rests upon you that which is of his glory, and of God's honor and power, and who is His Spirit. This «his» is possessive, and designates the angelic spirit (Hic possessivum est «eius» et angelicum spiritum significat). ${ }^{51}$

Once again, the «telescopic» view of the hierarchy is presupposed, so as to convey the presence of Christ through («per», presumably rendering $\delta^{\prime} \alpha$ ) the work of the lowest angelic level. ${ }^{52}$ Adumbrationes in 1 Pet 4:14 presents three entities: God; God's Glory / Honor / Power $(=\ll H e »)$; the Spirit of

the perfect identity between the Paraclete that is working (in the Church, and the Paraclete who was active in the prophets. I will return to this text in the second part of this essay.

49 The same phenomenon applies to the gift of philosophy to the pagans: the

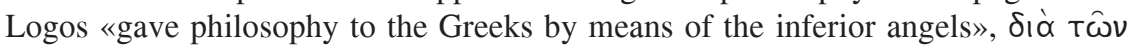

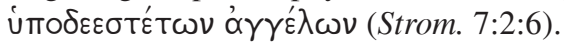

${ }^{50}$ Spiritus Christi could, in theory, be translated as a plural («spirits of Christ»); but

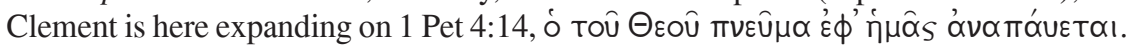

${ }^{51}$ Adumbrationes in 1 Pet 2:3; Adumbrationes in 1 Pet 4:14.

52 Oeyen (Engelpneumatologie... 27-28) and Hauschild (Gottes Geist... 79) identify the «angeli propinqui» with the protoctists. This interpretation appears to miss half of Clement's intention: the prophetic inspiration is, indeed, worked out through the protoctists, who are «close» to the Son; yet the movement is further transmitted in the same way to the archangels, who are «close» to the protoctists, and the angels, who are «close» to the archangels. Finally, the lowest angelic rank is the last element in the chain of prophetic inspiration: this is, for Clement, the «spirit» that rests upon the prophets. 
God's Glory / Honor / Power (= «His Spirit»). ${ }^{53}$ But the Spirit of Christ is treated, in a way that could hardly be more explicit, as a designation for angelic beings: archangels and kindred angels ... are called «the Spirit of Christ»; «his Spirit» is «the angelic spirit». For a full discussion of this topic, the reader is referred to Oeyen's Engelpneumatologie. For the time being, let us consider another relevant text:

And by one God are many treasures dispensed; some are disclosed through the Law, others through the prophets; some by the divine mouth, another

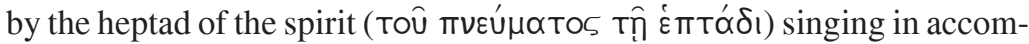
paniment. And the Lord being one, is the same Instructor in all of these. ${ }^{54}$

According to Schlütz this text describes the revelation of the Instructor Logos as both unitary and progressive: the Logos works in the law, later in the prophets, then in the Incarnation («the divine mouth»), and, finally, the descent of the Spirit at Pentecost. Oeyen prefers a direct equation of «the divine mouth» with the Spirit, on the basis of Protr. 9:82:1.55 On either view (and I argue that Clement's Spirit Christology, which will be discussed below, annuls their distinction), the expression «heptad of the spirit» refers to the Holy Spirit. This raises the problem of understanding the relation between Clement's expressions «heptad of the Spirit» and «protoctists». Is «holy spirit» a designation for the seven angels of the Face, or is «seven protoctists» a designation for the Holy Spirit? Briefly put: «angel» Pneumatology or «pneuma» angelology?

Ladaria prefers to interpret «angels» as references to the Holy Spirit. ${ }^{56}$ Similarly, Oeyen notes, commenting on the passage discussing the spiritus angelicus (Adumbrationes in 1 Pet 4:14): «nicht nur werden Engel Geist genannt; auch der Geist wird als engelhaft bezeichnet», and concludes «dass es sich ohne Zweifel um den Heiligen Geist handelt, und nicht um einen niedrigeren Engel, der Geist im abgeschwachten Sinne genannt würde». ${ }^{57}$ These observations amount to a distinction between «angelic» and «angelomorphic» Pneumatology. Indeed, Oeyen does not deny the Pneumatological content of passage: the seven first-created angels are the sevenfold Spirit in archaic «angelomorphic» language.

${ }^{53}$ For a discussion of the variant reading of 1 Pet 4:14, see Th. ZAHN, Forschungen zur Geschichte des neutestamentlichen Kanons und der altkirchlichen Literatur III: Supplementum Clementinum (Erlangen, 1884) 3: 95, n. 11; OEYEN, Engelpneumatologie... 28, n. 24.

${ }^{54}$ Paed. 3:12:87.

${ }^{55}$ K. SchlÜTZ, Isaias 11:2 (Die sieben Gaben des Heiligen Geistes) in den ersten vier christlichen Jahrhunderten (Münster 1932) 77; OEYEN, Engelpneumatologie... 27, n. 22.

${ }^{56}$ LADARIA, El Espíritu... 254.

${ }^{57}$ Oeyen, Engelpneumatologie... 28 (Oeyen's Italics). 


\section{Angelomorphic Pneumatology is not an Island}

The aim of the previous section has been to show that Levison's «angelic Spirit» continues on in early Christianity as angelomorphic Pneumatology. It seems that more has in fact been established: Revelation, the Shepherd, and certain passages from Clement of Alexandria reveal a very specific use of Jewish angelology in their reflection on the Holy Spirit. All three witnesses use the Second Temple theme of the seven supreme angels as a distinct and crucial (albeit not exclusive) building block for Pneumatology. The argument for angelomorphic Pneumatology seems to stand on solid ground. It could be strengthened by many more texts and authors; this will be the subject of future studies.

At this point it is important to inquire about the place of angelomorphic Pneumatology in the larger theological framework of our texts. Indeed, no theological phenomenon is an island! Angelomorphic Pneumatology occurs, as I will try to show, in tandem with Spirit Christology, as part of a binitarian theological framework. In what follows, I will first discuss the Spirit Christology, then also the binitarianism of Revelation, the Shepherd of Hermas, and Clement of Alexandria.

\section{Angelomorphic Pneumatology and Spirit Christology ${ }^{58}$}

\section{Spirit Christology in the Book of Revelation}

In all three texts dealt with above, «spirit» can also designate the Son of God.

The book of Revelation constructs a precise parallelism between the function of Christ and that of the «spirit» as described in the introductory and final parts of the seven letters (chs. 2-3). The letters are framed by an opening announcement of what Christ proclaims, and a final exhortation to hear

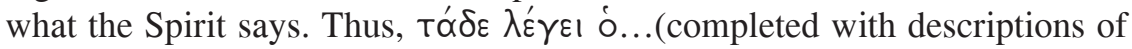

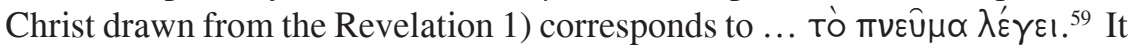
is clear that the parallelism is not an accident, and that the author consciously and consistently introduces a functional overlap between «Christ» and «Spirit». The scholarly treatment of the passage is somewhat disappointing. Commentators sometimes evade the difficulty simply by restating the obvious: the close relation between the Spirit and the exalted Christ, the fact that Christ speaks through the Spirit, etc.

${ }^{58}$ For the purpose of this paper, «Spirit Christology» refers to the use of $\pi \nu \varepsilon u ̂ \mu \alpha$ language to designate Christ in numerous pre-Nicene texts and authors. For a rich survey of texts, see M. Simonetti, Note di cristologia pneumatica // Augustinianum 12 (1972) 201-232.

${ }^{59} \operatorname{Rev} 2: 1-2: 7$; Rev 2:8-2:11; Rev 2:12-2:17; Rev 2:18-2:29; Rev 3:1-3:6; Rev 3:7-3:13; Rev 3:14-2:22. 
First, it must be said that, of the two terms, «Christ» can only refer to the Son of God. The question is, then, to determine what «spirit» stands for: the Holy Spirit, an angel, God as inspiring agent, something else? Given the prophetic-visionary character of the textual unit Revelation 2-3, «spirit» is, in all likelihood connected to the reality of prophetic vision. This is the point where scholarly opinions begin to diverge. Schweitzer takes «Spirit» as a Christological title, derived from the act of Christ's inspiring the prophet: «the Spirit is none other than ... the Ascended Christ in his role of speaking to the Church». ${ }^{60}$ F. F. Bruce holds the opposite position: «it is not that the Spirit is identical to the exalted Lord, but that the exalted Lord speaks to the Churches by ... the Spirit of prophecy ... When the spirit of prophecy comes upon him, John speaks of himself as being, or becoming, "in the Spirit" ('

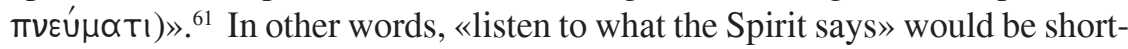
hand for «listen to what Christ says through the one who was in the spirit».

As can be seen, the divergence can be reduced to the issue of whether «Spirit» should be relegated to the seer (Bruce), or to Christ (Schweitzer). Be that as it may, one thing is certain: $\pi v \varepsilon \hat{u} \mu \alpha$ here is not the Holy Spirit. ${ }^{62}$

Schweitzer's position seems more plausible, because it accounts better for the parallelism Christ — Spirit noted above, and also because it offers the simpler solution, in comparison to transformation of Tò $\pi v \varepsilon u \hat{u} \alpha \lambda \lambda^{\prime} \gamma \varepsilon$ into

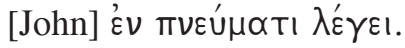

The hypothesis of Spirit Christology in the Book of Revelation has the advantage of accounting for the functional overlap between the «Christ» and «Spirit» without necessarily implying a simple identity between Christ and the Spirit. The identification between the OT «Spirit of God» and the NT «Spirit of Christ» is ultimately Christologically motivated, since it identifies Christ as divine. ${ }^{63}$

${ }^{60}$ Schweitzer, Spirit of God... 105.

${ }^{61}$ F. F. Bruce, The Spirit in the Apocalypse // Christ and Spirit in the New Testament: In Honour of C. F. D. Moule / Ed. B. Lindars, S. Smalley (Cambridge, 1973) 340, 339. The same position is adopted by R. BAUCKHAM, in his book The Climax of Prophecy: Studies on the Book of Revelation (Edinburgh, 1993) 160-161.

${ }^{62}$ Contra Ch. Brütsch, La clarté de l'Apocalypse (Geneva, 1966) 58, who does not even debate the matter: «l'Esprit: indubitablement, le Saint-Esprit» (Italics mine).

${ }^{63}$ Indeed, as M. FATEHI states repeatedly (The Spirit's Relation to the Risen Lord in Paul (Tübingen, 2000) (WUNT, 128), no mediator figure among the so-called exalted, angelomorphic patriarchs is ever presented as having the same relation to the Spirit that the OT affirms of God and His Spirit. An older formulation of this thesis can be found in M. Turner, The Spirit of Christ and «divine» Christology, in // Jesus of Nazareth: Lord and Christ: Essays on the Historical Jesus and New Testament Christology / Ed. J. B. GreEn, M. Turner (Grand Rapids, 1994) 413-436. 


\section{Spirit Christology in the Shepherd of Hermas}

When thinking of the Shepherd's oft-debated Spirit Christology, one text immediately leaps to mind: filius autem spiritus sanctus est (Sim 5.5.2). This verse, however, makes a symbolic identification between the «son» in the parable, on the one hand, and this character's symbolized counterpart, the Holy Spirit, on the other. But there are other relevant passages in the Shepherd.

In Sim 9.1.1, Hermas is told that the one who spoke to him in visions was

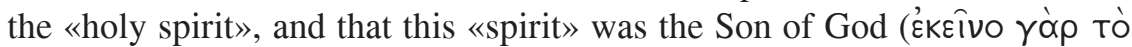

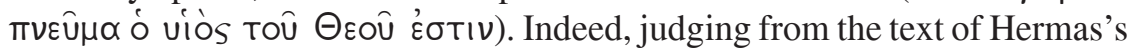
prayer (Vis 3.1.2: «when I had fasted a great deal and asked the Lord to show me the revelation he had promised to show me...»), one would expect the response to come from «the Lord» as well. The «spirit», then, is the «Lord», that is, Son. ${ }^{64}$

In Sim 5 the Shepherd speaks about God sending the preexistent Holy

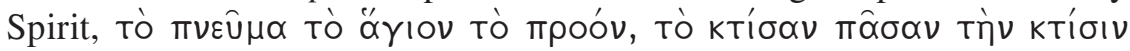
(Sim 5.6.5). We find a clarifying parallel in Sim 9.12.1-2, where the state-

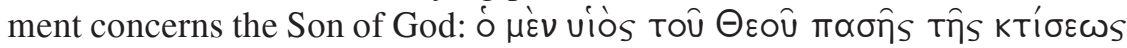

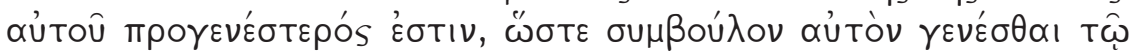
патрі. The identical descriptions of the Son and the Spirit agree with the statement in Sim 9.1.1: the Spirit is the Son of God. There is only one subject: not the «polymorphic Holy Spirit» — pace Gieschen — but rather the Son of God, who is, technically, a «holy spirit». ${ }^{65}$ To this highest «spirit» are subordinated all other «spirits», such as, for instance, the virgins discussed above.

${ }^{64}$ The title «Son» can be derived from the following two solemn declarations, whose crucial importance is highlighted by the fact that they appear at the climax of the so-called heavenly letter, preceded by a fifteen-day long fast: «The Lord (kúpı os) has sworn on his Son that those who deny their Lord (kúpıos) have been disenfranchised from their life» (Vis 2.2.8). While the first kúpıos refers to God, the second one obviously designates the Son. This is also the idea underlying several text witnesses: L1 and E have «filium», while $\mathrm{S}^{*}$ reads Xpı otóv — see Joly, in SC 53, pp 92-93, n. 5. The reference to «their Lord» is significant, as it parallels Sim 5.5.3 and Sim 5.6.4, where the Son of God is proclaimed as «Lord of the people». A theology advocating «two Lords» is rightly termed «binitarian monotheism».

${ }^{65}$ According to Gieschen, all revelational characters (including the Son / slave / flesh) are «a manifestation of the Spirit», in the context of «a very fluid angelomorphic Pneumatology» (Angelomorphic Christology 222, 225). The idea of a secondcentury version of binitarian monotheism featuring not the Son, but the Spirit as God's vice-regent and sole polymorphic mediator has been pursued further by M. R. BARNES («Early Christian Binitarianism: The Father and the Holy Spirit», paper read at the North American Patristics Society in 2001, online at www.mu.edu/maqom/barnes). 


\section{Spirit Christology in Clement of Alexandria}

Clement frequently uses «Logos» and «Pneuma» as synonyms, switching between them repeatedly and without much explanation. ${ }^{66}$

In Strom. 5:6, Clement ascribes the creation and sustenance of the cosmos, and the divine revelation to humankind, to the «Name», «Son», «Savior», or «Logos». Nevertheless, the Word's role in organizing the cosmos and in prophetic revelation is illustrated by a quote from 1 Cor 12:11 («the self-same Holy Spirit works in all»). Moreover, the Scripture verse is soon afterwards reworked in a Christological key: «God the Savior works ... it is the same Logos which prophesies, and judges, and discriminates all things». There seems to be a perfect parallel between the reference to the Spirit and the reference to the Son: both are introduced as inspired, prophetic ideas («the apostles were at once prophets and righteous»; «the oracle exhibits the prophecy which by the Word cries and preaches... since it is the same Word

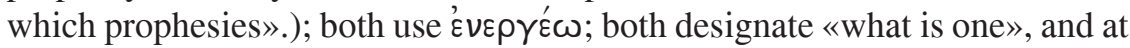
the same time becomes «what is many». It seems that Clement operates a translation sui generis of Cor 12:11 into his own theological idiom: the «Spirit» mentioned by the Apostle is identified as the Logos.

In Excerpta 24:2, a text directed against the dualist views of the Valentinians, Clement affirms the perfect identity (i.e., an identity of ovoía and $\left.\delta \delta^{\prime} v \alpha \mu \varsigma\right)$ between the Paraclete that is working ( $\left.\varepsilon v \varepsilon \rho \gamma \hat{\omega} v\right)$ in the Church,

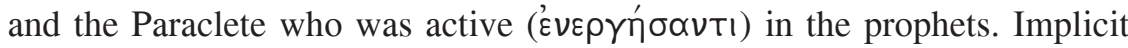
here is the identification of Paraclete with the Logos, because (a) Clement had previously affirmed that it is the Logos who was at work in the prophets

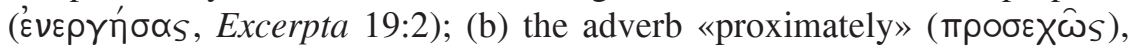
qualifying the action of the Paraclete, functions as a technical term in Clement's description of how the Logos transforms the perfect souls towards god-

${ }^{66}$ Paed. 1:6:43: «the Lord Jesus, the Word of God, that is, the Spirit made flesh». Commenting on the fourth commandment of the Decalogue, Clement explains: «The seventh day, therefore, is proclaimed a rest ... preparing for the Primal Day, our true rest; which, in truth, is the first creation of light, in which all things are viewed and possessed. ...For the light of truth, a light true, casting no shadow, is the Spirit of God indivisibly divided to all... By following Him, therefore, through our whole life, we become impassible; and this is to rest» (Strom. 6:16:138). «Day» and «true Light» are quite transparently referring to Christ (cf. John 1:4-8; 8:56), as becomes clear immediately afterwards, when the text speaks about following Christ. However, the latter's identity is, in this passage, «Spirit of God». Clement is obviously drawing on an archaic Christology designating the preexistent Christ as $\pi \nu \varepsilon \hat{\cup} \mu \alpha$, interchangeably with $\lambda$ óyos. This seems to be a widespread phenomenon, present in Syria-Palestine, Alexandria, Carthage, and Rome, in authors speaking Latin, Greek and Syriac. See the texts and analyses in Simonetti, Note..., and R. Cantalamessa, L'omelia in S. Pascha dello Pseudo-Ippolito di Roma. Ricerche sulla teologia dell'Asia Minore nella seconda metà del II secolo (Milano, 1967) 171-185. 
likeness (Excerpta 27:3;27:6). It is the same term used to describe the lack of any interval between the levels of the celestial hierarchy.

The same exegetical procedure occurs in Excerpta 17: Clement discusses

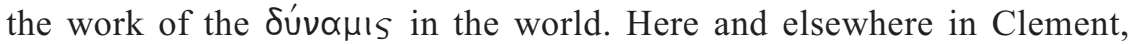
$\delta$ úvauss is a Christological term. ${ }^{67}$ The Biblical proof texts, however, are, once again, references to $\pi v \varepsilon \hat{\mu} \mu \alpha$ : John 4:24 («God is Spirit») and John 3:8 («He blows wherever He desires»).

Clement ends Strom. 4:26:172 with the following words: «I shall pray the

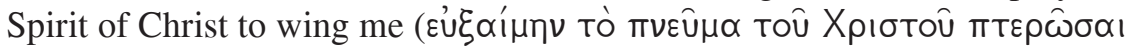
$\mu \varepsilon)$ to my Jerusalem». Very similarly, the final hymn of the Instructor calls upon Christ as the «wing (

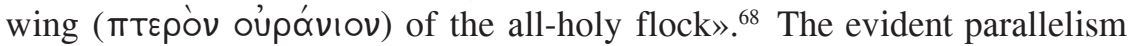
between the invocations in Strom. 4:26:172 and Paed 3:12:101 suggests that «Spirit of Christ» is simply Christ in his function of heavenly guide.

There are at least three factors that determine the overlap between Spirit and Logos. First, Clement deploys an all-encompassing theory of the Logos, and thereby inevitably claims for the Logos certain areas of activity traditionally associated with the Spirit, namely the inspiration of Scripture and the charismatic empowerment of the believer. ${ }^{69}$ Second, Clement follows the Philonic model of «translating» Scriptural terms and images into philosophical concepts, and «explains» the Biblical $\pi v \varepsilon u \hat{u} \alpha$ in light of the philosophi-

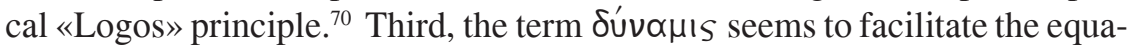
tion of Spirit and Logos, insofar as Clement uses it alternatively for the Logos and the Spirit. ${ }^{71}$

${ }^{67}$ Excerpta 4:2; 12:3; Strom. 7:2:7; 7:2:9. See also Sagnard's comments in Excerpta, 79 , n. 2.

${ }^{68}$ Instructor 3:12:101.

${ }^{69}$ Cf. Zahn, Forschungen, 98: [der Geist] «den er wie die Alten so oft in seinen Speculationen über das Verhältnis des Logos zu Gott und zur Welt regelmässig übergeht»; Kretschmar, Trinitätstheologie, 63: «im allgemeinen denkt er [Klemens] logozentrisch, der Geist tritt zurück». Ladaria (El Espíritu... 25) notes that the Spirit's «efficient causality» in the phenomenon of inspiration is equally applied to the Logos or Kyrios, especially in the Instructor. He believes, however, that these coincidences do not amount to an identification of the Word and the Spirit.

${ }^{70}$ Simonetti (Note di cristologia pneumatica... 209) thinks primarily of Stoic influence: «In ambienti culturalmente impregnate e perciò apperti all'influsso stoico avrà operato in tal senso anche l'identificazione fra logos e pneuma». Lilla and Osborn argue for Middle Platonism.

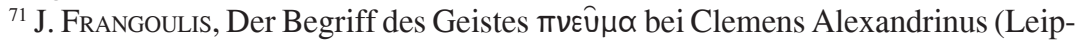
zig, 1936) 16, also makes a brief note to this effect: «[es] findet sich bei Clemens auch eine enge Verbindung von Pneuma und Sohn in dem übergeordneten Begriff

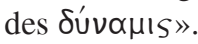


The very same texts that instantiate an early Christian angelomorphic Pneumatology are also familiar with a different use of $\pi v \varepsilon u ̂ \mu \alpha$ : «Spirit» as a designation of the second divine Person. Angelomorphic Pneumatology and Spirit Christology are closely linked and form a «tandem» that can be detected in all three texts discussed above, as well as in other early Christian writings. The connection between Angelomorphic Pneumatology and Spirit Christology is hardly surprising, since both depend on the notion of $\pi \nu \varepsilon \hat{u} \mu \alpha$ as a celestial entity. Spirit Christology can be understood as a Christological reworking of the «angelic spirit», one in which the Son of God is conceived of as the highest such «spirit». Needless to say, such use of «spirit» language in the service of Christology is widespread in early Christianity. ${ }^{72}$

One other element that must be taken into account is the binitarian framework associated with the combination of angelomorphic Pneumatology and Spirit Christology.

\section{A Binitarian Theological Framework}

A certain binitarian monotheism, positing a «second power in heaven», God's vice-regent, is an important part of Christianity's Jewish roots. ${ }^{73}$ Indeed, the «second power» - the Glory, the Name, the Wisdom, the Power, the Angel, the Son of Man - was bound to «become a central metaphor for Christ in Christianity». ${ }^{74}$ In the New Testament, this is especially obvious in the Fourth Gospel and the Pauline Corpus. Towards the middle of the second

${ }^{72}$ Ch. STEAd, Philosophy in Christian Antiquity (Cambridge, 1994) 155-156; R. C. Lilla, Clement of Alexandria: A Study in Christian Platonism and Gnosticism (London, 1971) 26, 53; F. Loofs, Theophilus von Antiochien Adversus Marcionem und die anderen theologischen Quellen bei Irenaeus (Leipzig, 1930) (TU, 46) 114205; SimonetTi, Note di cristologia pneumatica... 230-231; B. STUDER, La Soteriologie de Lactance // Lactance et son temps: Recherches Actuelles. Actes du IV ${ }^{\mathrm{e}} \mathrm{Col}-$ loque d'Etudes Historiques et Patristiques, Chantilly 21-23 septembre 1976 / Ed. J. Fontaine, M. Perrin (Paris, 1978) 252-271, here 259-260, 270-271.

${ }^{73}$ An excellent collection of relevant articles is found in J. R. DaviLA et al. (eds.), The Jewish Roots of Christological Monotheism: Papers from the St. Andrews Conference on the Historical Origins of the Worship of Jesus (Leiden, 1999). See also A. Segal, Two Powers In Heaven: Early Rabbinic Reports About Christianity and Gnosticism (Leiden, 1977); M. BARKER, The Great Angel: A Study of Israel's Second God (Westminster, 1992); G. Quispel, Der Gnostische Anthropos und die Jüdische Tradition // Gnostic Studies I (Istanbul, 1974) 173-195; J. Fossum, Gen. 1:26 and 2:7 in Judaism, Samaritanism and Gnosticism // JSJ 16 (1985) 202-239; P. A. RAInBow, Jewish Monotheism as the Matrix for New Testament Christology: A Review Article // NT 33 (1991) 78-91; IDEM, Monotheism - A Misused Word in Jewish Studies? // JJS 42 (1991) 1-15.

${ }^{74}$ A. SEgal, Paul the Convert. The Apostolate and Apostasy of Saul the Pharisee (New Haven-London, 1990) 41. 
century, when Justin Martyr writes his Dialogue with Trypho, this type of binitarian monotheism was still accepted by both Christians and Jews, the dividing issue being the Christian identification of Jesus with the «second God». On the way to a mature Trinitarian theology, a certain binitarian tendency is often noticeable among Christian authors. ${ }^{75}$

How do we recognize whether a text is unitarian, binitarian, trinitarian? I appeal here to the principle developed by Larry Hurtado, which may be reduced to the following formula: that which is considered «God» is necessarily the object of worship; and that which is the object of worship is considered $« \mathrm{God} » .76$

It is with this perspective in mind that I ask the question: «Who is 'God' in the Book of Revelation?» The specific Jewish-Christian indicators of a belief in God are abundantly present in this text: the divine name, the divine throne, the worship. All three indicators point to the same theological view: God and His Son. The bearer of the divine name is the Father $(\operatorname{Rev} 1: 4,8 ; 4: 8 ; 11 ; 17$; $15: 3 ; 16: 7,14 ; 19: 6,15 ; 21: 22) ;{ }^{77}$ but a variation of the divine name is also attributed to the Son. ${ }^{78}$ The divine throne is occupied jointly by the Father

${ }^{75}$ See, in this respect, Loofs, Theophilus... 114-205; SimonetTi, Note di cristologia pneumatica... 230-231; W. MACHOLZ, Spuren binitarischer Denkweise im Abendlande seit Tertullian (Jena, 1902); E. Osborn, Clement of Alexandria (Cambridge, 2005) 152.

${ }^{76}$ L. Hurtado, At the Origins of Christian Worship (Grand Rapids, 1999); IDEM, Lord Jesus Christ: Devotion to Jesus in Earliest Christianity (Grand Rapids, 2003) Esp. 11-53.

77 The fact that «He-Who-Is» functions as a stand-in for YHWH explains why the writer refuses to subject the Name to the rules of declension in Rev 1:4. Prigent (Commentary on the Apocalypse... 115) explains the following: «it is impossible to suppose that ... it was not deliberate, especially since the same expression is repeated later $(1: 8 ; 4: 8 ; 11: 17 ; 16: 5)$ with the same persistence in making a noun out of the imperfect form of the verb "to be". ...the titles of the eternal God cannot be subjected to temporal vicissitudes, and consequently to the laws of noun declension. The God in question is one who can only act as subject».

${ }^{78}$ See Aune, Revelation... 1:51-59; S. McDonough, YHWH at Patmos (Tübingen, 1999) (WUNT, 107) 195-231. Martin McNamara found that the passage «is perfectly paralleled in TJI Dt 32, 39 and in this text alone of those available to us... It is not to be excluded that the Apocalypse is directly dependent on TJI Dt 32, 39 in its use of it, although it is possible that both texts are dependent on the same early liturgical tradition» (M. McNamara, The New Testament and the Palestinian Targum to the Pentateuch (Rome, 1966) (Analecta Biblica, 27) 98-112, here 112). Whether the author of Revelation draws on Jewish or Greek traditions, or perhaps on a fusion of both, he is also subjecting the preexisting formulae to his own theological views. For instance, his eschatological perspective dictates an original modification of the third member of the Dreizeitenformel from «who will be» to «who will come» (so BEN Witherington III, Revelation (Cambridge-New York, 2003) 75). 
and the Lamb. And, most importantly, worship is given to the God and His Son, or Lamb. ${ }^{79}$ Within this binitarian framework, the Spirit appears at the same time indissolubly linked to the worshipped second person («seven horns of the Lamb», «seven eyes of the Lord», «seven stars in the Lord's hand»), and strictly subordinated to it («the seven holy spirits before the throne»).

Since the binitarianism of the Shepherd of Hermas requires no further exposition, I move directly to Clement of Alexandria. Some decades ago, W. H. C. Frend stated bluntly that «Clement's theology was really binitarian», and that although «he mentions the Spirit as the agent of Faith in the believer, there would appear to be little real place for Him in his system». ${ }^{80}$ More recently, Henning Ziebritzki concludes, after a detailed study, that Clement has virtually no Pneumatology, and hence no conception yet of a third hypostasis. ${ }^{81}$

Approaching matters from a different angle, and using Hurtado's principle, one comes to the same conclusion: Clement is very reluctant to include the Spirit as a recipient of worship. ${ }^{82}$ He sometimes presents the Fa-

79 «Then I heard every creature in heaven and on earth and under the earth and in the sea, and all that is in them, singing, "To the one seated on the throne and to the Lamb be blessing and honor and glory and might forever and ever!" And the four living creatures said, "Amen!" And the elders fell down and worshiped» (Rev 5:13$14)$; «Then the kings of the earth and the magnates and the generals and the rich and the powerful, and everyone, slave and free, hid in the caves and among the rocks of the mountains, calling to the mountains and rocks, "Fall on us and hide us from the face of the one seated on the throne and from the wrath of the Lamb; for the great day of their wrath has come, and who is able to stand?"» (Rev 6:15-17); "Salvation belongs to our God who is seated on the throne, and to the Lamb!» (Rev 7:10); "Over these the second death has no power, but they will be priests of God and of Christ, and they will reign with him a thousand years» (Rev 20:6); «They have been redeemed from humankind as first fruits for God and the Lamb...» (Rev 14:4); «I saw no temple in the city, for its temple is the Lord God the Almighty and the Lamb. And the city has no need of sun or moon to shine on it, for the glory of God is its light, and its lamp is the Lamb» (Rev 21:22-23).

${ }^{80}$ W. H. C. Frend, Martyrdom and Persecution in the Early Church: A Study of a Conflict from the Maccabees to Donatus (Garden City, NY, 1967) 264.

${ }^{81}$ ZIEBRITZKI, Heiliger Geist... 123: «Klemens hat explizit den Heiligen Geist weder in seiner individuellen Substanz begriffen, noch seinen metaphysischen Status auch nur ansatzweise bestimmt. Damit fehlen aber auch die entscheidenden Voraussetzungen, die es erlauben würden, im klementinischen Verständnis des Heiligen Geistes den Ansatz zum Begriff einer dritten göttlichen Hypostase zu sehen». For a more favorable assessment of Clement's efforts, see E. Osborn, Clement of Alexandria (Cambridge, 2005). I engage Osborn's view at length in my Revisiting Christian Oeyen (referred to above).

${ }^{82}$ The hymn to Christ, at the end of the Instructor mentions hymns of praise addressed either to the Father, or to the Son, or to both — but never to the Holy Spirit. 
ther alone receiving praise through ( $\left.\delta^{\prime} \alpha\right)$ the Son and the Holy Spirit. ${ }^{83}$ Especially significant are the instances in which Clement suggest a subordination of the Holy Spirit to both the Father and the Son. For instance, in the following passage he calls only the Father and the Son «God»: «they know not what a "treasure in an earthen vessel" we bear, protected as it is by the power of God the Father, and the blood of God the Son, and the dew of the Holy Spirit». ${ }^{84}$

Clement is of course aware of Trinitarian formulae. However, the framework of his theology is binitarian. Within this framework, the angelomorphic Spirit appears as subordinated to the second Person (the protoctists ministering before the Face of God, «the powers» of the Logos / Spirit), and as the «instrument» by which the Logos operates in creation.

The second part of this essay has now come to an end. The question was to establish whether or not there are specific theological elements associated with angelomorphic Pneumatology. It is a fact that in all three texts - Revelation, Shepherd, and the Clementinian passages - angelomorphic Pneumatology occurs in a binitarian theological framework, and alongside Spirit Christology. It makes good sense, therefore, not to consider angelomorphic Pneumatology in itself, but rather in relation to Spirit Christology and binitarianism, as part of a larger theological whole. The articulation of angelomorphic Pneumatology, Spirit Christology and binitarianism can be summed up in the formula «Father, Son / Spirit, and angelomorphic Spirit». The question at this point is how to interpret these data.

\section{Theological Interpretation}

Measured against the standard of later Orthodoxy, Revelation, the Shepherd and Clement appear seriously inadequate. In historical perspective, however, angelomorphic Pneumatology is simply a phase in Christian reflection on the Holy Spirit. The use of Second Temple themes, such as the «angelic spirit» and the apocalyptic «angels of the Face», as building-blocks in the articulation of early Christian Pneumatology, illustrates the general indebtedness of pre-Nicene theology to the categories inherited from Second Temple

In the closing chapter of the Instructor (Paed. 3:12:101) praise, glory, worship are directed «to the only Father and Son, Son and Father, the Son - Instructor and Teach-

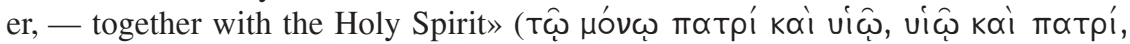

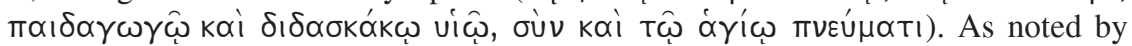
Ziebritzki (Geist und Weltseele... 124), the reference to the Holy Spirit seems a mere afterthought.

${ }^{83}$ E.g., Quis Dives 42:20.

${ }^{84}$ Clement of Alexandria, Quis Dives 34:1. 
Judaism. Angelic and angelomorphic Pneumatology occurs (in full-blown form, or merely as remnants of older tradition) in many other texts and authors. This way of thinking and speaking about the Holy Spirit was still an option in the fourth century. ${ }^{85}$ However, with the advent of the new theological paradigm in the wake of the Arian and Pneumatomachian controversies, the angelomorphic Holy Spirit became highly problematic, and ultimately a theological liability. So much can be said from a historical perspective. A few notes from a systematic theological point of view are now in order.

First, it is useful to remind ourselves constantly of the fact that using terms such as «angelomorphic Pneumatology» or «Spirit Christology» we affirm something about the author's theological language, not about the theological reality signified by the language. These terms are not meant as a description of the Godhead, but rather as an aid to understand how an author or a text chooses to speak about things divine.

Second, there exists in early Christianity a certain incongruence between the «creedal» level of theology (i.e., what is defined as normative faith) and the «functional» level of theology (i.e., how faith is expressed theologically). Obviously, articulating a Trinitarian doctrine, in order to reflect a Trinitarian experience of God, took longer than the introduction of Trinitarian formulae.

Third, the overlap of Christ and the Spirit («Spirit Christology»), and the overlap of divine and angelic manifestation («angelomorphic Spirit») stem from the functional identity of Christ, the Holy Spirit and the angel as grasped by religious experience. Many of the passages discussed in this essay describe the divine action upon the believer, and especially (perhaps paradigmatically) the divine action in the prophet. ${ }^{86}$ It is legitimate to say, then, that

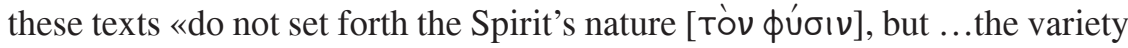

${ }^{85}$ See the brief summary in R. P. VAGGIOnE, Eunomius of Cyzicus and the Nicene Revolution (Oxford, 2000) 122-123 (discussion) and n. 270 (patristic references).

${ }^{86}$ Most passages in Clement which contain angelomorphic Pneumatology (e.g., in the Adumbrationes) center around the phenomenon of prophecy. In his hierarchy, the lowest angelic rank, and, by consequence, the one closest to the human world, transmits the divine «movement» to the prophet. Clearly, the prophet represents the highest level in the human hierarchy, the link with the celestial realm. A few centuries later, the Ps.-Areopagite will assign this position to the bishop. Clement, instead, seems much closer on this issue to the Shepherd (Mand 11:9), for whom the point of contact between the inspiring angel and the community of believers is the prophet. In Revelation, the statement about the angel being «a fellow servant» with the prophet (Rev 19:10; 22:8-9) may serve, on the one hand, to correct any angelolatric tendencies (cf. Tobit 12:16-22; Col 2:18, Ascension of Isaiah 7:21-23; 8:4-5; Apocalypse of Zephaniah 6:13-15); but, on the other hand, «John's purpose was ... perhaps, to claim for his brothers a certain primacy in the affairs of churches» (M. KIDDLE, The Revelation of St. John (London, 1963) 449). 


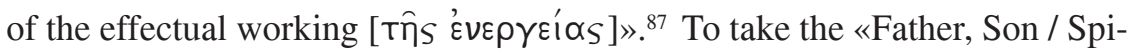
rit, and angelomorphic Spirit» scheme as a (very deficient) statement on theologia rather than oikonomia would be not only an anachronism, but also a theological misinterpretation.

Finally, the prophetic-visionary context of the writings discussed in this essay should also lead the reader to recognize their mystagogic role. This aspect is most explicit in the Shepherd: again and again we see that with Hermas's spiritual growth his perception of celestial realities and ability to comprehend their meaning also improve. ${ }^{88}$ Revelation, the Shepherd, and the Clementinian writings are simply not designed to be approached like extraneous objects. Their function is rather to draw the reader into reenacting the same type of dynamic message-appropriation which they narrate. ${ }^{89}$ What, then, of the angelomorphic description of the Spirit? We should perhaps borrow a page from Hermas: Sir, I do not see the meaning of these similitudes, nor am I able to comprehend them, unless you explain them to me (Sim 5.3.1, ANF)."

${ }^{87}$ Basil the Great, De Spirit 8:17. Along the same lines, I find it interesting that the angelomorphism of the Spirit reemerges in the writings of no less than the champion of Byzantine theology in the fourteenth century, Gregory Palamas. This author is uninhibited in using precisely those Biblical verses that had once supported angelomorphic Pneumatology. In his Fifth Antirhetikos Against Akindynos (chs. 15; 17), Gregory Palamas identifies the seven gifts of the Spirit in Isaiah 11 with the seven eyes of the Lord (Zech 4:10), the seven spirits of Revelation, and the «finger / spirit of God» (Luke 11:20; Mat 12:28): all of these, he says, designate the divine energies referred to in Scripture as seven, and should therefore not be considered created. The exact same cluster of passages occurs also in Palamas' One Hundred and Fifty Chapters (70-71).

88 «...the angel of repentance, he came to me and said, 'I wish to explain to you what the Holy Spirit that spoke with you in the form of the Church showed you, for that Spirit is the Son of God. For, as you were somewhat weak in the flesh, it was not explained to you by the angel. When, however, you were strengthened by the Spirit, and your strength was increased, so that you were able to see the angel also, then accordingly was the building of the tower shown you by the Church. In a noble and solemn manner did you see everything as if shown you by a virgin; but now you see [them] through the same Spirit as if shown by an angel. You must, however, learn everything from me with greater accuracy...» (Sim 9.1.1, ANF).

${ }^{89}$ I have found inspiration in the similar treatment of Origen and Evagrius proposed by V. Niculescu, in his articles: Spiritual Leavening: The Communication and Reception of the Good News in Origen's Biblical Exegesis and Transformative Pedagogy // JECS (forthcoming); Coping With the Grief of Ignorance: Evagrius Ponticus's Hermeneutics of the Distance Between God and Humanity // Arches 7 (2004) 107-120 (also available online at www.arches.ro).

* I am very grateful to Dr. James Miller and Hieromonk Dr. Alexander Golitzin, who proofread advanced drafts of this paper, and provided critical feedback. Any remaining errors are my sole responsibility. 


\section{ABSTRACT}

Building on John R. Levison's study on «The Angelic Spirit in Early Judaism», which documented the widespread use of the term «spirit» as a designation for an angelic presence, this essay argues the presence of an «angelomorphic Pneumatology» in three early Christian sources: the book of Revelation, the Shepherd of Hermas, and Clement of Alexandria. It is argued that angelomorphic Pneumatology occurs in tandem with Spirit Christology, within a binitarian theological framework. This larger theological articulation results in a quasi-Trinitarian structure of the divine world, featuring the Father, the Son/Spirit, and the angelomorphic Spirit. The final section of the essay proposes a theological interpretation of these data. 